\title{
Alarming lack of knowledge about antithrombotic therapy among patients with atrial fibrillation
}

\author{
Terapia antitrombótica: alarmante falta de conhecimento em pacientes com fibrilação \\ atrial \\ Julia Miguel Leitão', Fernanda Maria Dutra Spagnuolo Moreira1', Ingrid Eyng Thiel', Isadora Yasbick \\ Spricido', Rômulo Henrique Malaquias Silva', Viviane Flumignan Zétola²
}

\begin{abstract}
Large population campaigns have been conducted in Brazil to improve knowledge about the signs and symptoms of stroke and the importance of time to care. Objective: Parallel to these important actions, we aimed to evaluate the lay knowledge of patients with atrial fibrillation, a well-recognized etiology of stroke, adequate treatment and management of which can prevent up to $30 \%$ of cerebrovascular events. Methods: We questioned 143 patients with atrial fibrillation about the risks associated with the disease. Results: Ninety-one percent were on anticoagulation treatment. Of the total, $63.6 \%$ reported having been informed about the risks and benefits of anticoagulants but only $46.9 \%$ were able to correctly mention one of these risks. Ischemic stroke was identified as a risk by only $25.9 \%$ and hemorrhagic stroke was not mentioned. A CHADS $2 \geq 2$ was scored by $84.0 \%$ of the patients. Conclusions: Our study showed an alarming knowledge gap in patients with atrial fibrillation. Difficulty in adherence to treatment resulting from the failure of this communication is possibly one of the factors responsible for the high incidence and recurrence of stroke, and should not go unnoticed.
\end{abstract}

Keywords: Atrial fibrillation; stroke; patient medication knowledge; warfarin; anticoagulants.

\section{RESUMO}

Campanhas populacionais para melhorar o conhecimento sobre os sinais e sintomas do acidente vascular encefálico e a importância do tempo para o tratamento têm sido realizadas no nosso país, visando a melhoria da linha do atendimento. Objetivo: Paralelamente a estas relevantes ações, objetivamos avaliar o conhecimento leigo de pacientes portadores de fibrilação atrial, etiologia determinada e prevalente do acidente vascular encefálico, cujo tratamento e manejo adequado podem prevenir até 30\% dos eventos cerebrovasculares. Métodos: Entrevistamos portadores de fibrilação atrial sobre os riscos associados à doença. Resultados: Noventa e um por cento estavam sob uso de anticoagulantes. Do total, 63,6\% responderam terem sido informados sobre riscos e benefícios da terapia anticoagulante, mas apenas 46,9\% souberam citar corretamente um desses riscos. Acidente vascular encefálico isquêmico foi associado ao risco por apenas 25,9\% e acidente vascular encefálico hemorrágico não foi mencionado. CHADS $2 \geq 2$ foi pontuado por $84,0 \%$ dos pacientes. Conclusões: Nosso estudo demonstra uma alarmante falha no conhecimento do risco de acidente vascular encefálico nos portadores de fibrilação atrial. Dificuldade na aderência ao tratamento resultante da falha dessa comunicação é fator relevante na incidência e recorrência do acidente vascular encefálico e não deve ser negligenciado.

Palavras-chave: fibrilação atrial; acidente vascular cerebral; conhecimento do paciente sobre a medicação; varfarina; anticoagulantes.

Large population campaigns have been conducted in Brazil to improve knowledge about the signs and symptoms of stroke and the importance of time to care. Along with receiving the correct treatment, prevention by all means must be a priority to reduce the morbidity and mortality of stroke.

Atrial fibrillation $(\mathrm{AF})$ is a supraventricular arrhythmia that leads to a total disorganization of atrial electrical activity, impairing the atrium's contraction capacity and inhibiting the sinus node ${ }^{1}$. Stroke is the main complication of AF. At least one in five strokes is associated with $\mathrm{AF}$, and thromboembolic strokes in patients with AF are usually more severe and incapacitating than in patients without $\mathrm{AF}^{2,3}$. More than 100,000 deaths due to stroke are registered annually in Brazil ${ }^{4}$. Stroke is also one of the main causes of death and is the major cause of disability in Brazil and in the world ${ }^{2,5,6,7}$.

'Universidade Federal do Paraná, Curitiba PR, Brasil;

¿Universidade Federal do Paraná, Hospital de Clínicas, Serviço de Neurologia, Curitiba PR, Brasil.

Correspondence: Viviane Flumignan Zétola; Hospital de Clínicas da UFPR, Serviço de Neurologia; Rua General Carneiro, 181; 80060-900 Curitiba PR, Brasil; E-mail:viviane.zetola@gmail.com

Conflict of interest: There is no conflict of interest to declare.

Received 04 April 2018; Received in final form 11 July 2018; Accepted 27 August 2018. 
Chronic therapy with oral anticoagulant drugs plays a crucial role in AF treatment by significantly avoiding the risk of thromboembolic stroke, although it brings a risk of intracerebral, or other hemorrhage ${ }^{8}$. Warfarin remains the most frequent oral anticoagulant prescribed in Brazil due to its efficiency and low cost $t^{6,9,10,11}$.

Risk stratification of thromboembolic events helps identify which patients have a stroke risk, and this clarifies the anticoagulant therapy ${ }^{12}$. Although the congestive heart failure, hypertension, age $\geq 75$ years, diabetes mellitus, stroke, vascular disease, age 65-74 years, sex category $\left(\mathrm{CHA}_{2} \mathrm{DS}_{2}\right.$ VASc) ${ }^{13}$ score has been proposed by vascular physicians, the congestive heart failure, hypertension, age $\geq 75$ years, diabetes mellitus, stroke $\left(\mathrm{CHADS}_{2}\right)$ score is one of the main scales used for thromboembolic risk evaluation in patients with AF by nonspecialists ${ }^{6,14,15}$. Treatment success in AF is highly correlated with patients' understanding about their condition and therapy complications. Prevention of cerebrovascular diseases must be one of the priorities in patient education, as the layperson's recognition of its signs and symptoms remains poor ${ }^{16,17,18}$.

We aimed to evaluate patients' knowledge about antithrombotic therapy in AF. We also evaluated whether the therapeutic orientation received by the patient correlated with the $\mathrm{CHADS}_{2}$ score.

\section{METHODS}

A cross-sectional study was conducted in a Brazilian Public University Hospital from September 2015 to May 2016. A total of 150 outpatients were interviewed, seven of whom did not meet the inclusion criterion. They were recruited from neurology and cardiology clinics. The inclusion criterion was patients who had been assisted by physicians at least once after receiving the diagnosis of AF. The study excluded patients with cognition impairment reported by caregivers, and those who did not sign the consent form.

A questionnaire with seven questions related to AF disease and its treatment was applied to the participants. Question 1 was about the patient's identification (age and gender). Question 2 asked if the patient had attended at least one medical appointment after receiving the diagnosis of AF. If the answer was 'yes' we continued with the next five questions. Question 3: "What is the treatment suggested by your doctor?" Question 4: "Did someone explain to you the risks in case of nonadherence to the anticoagulant treatment?" Question 5: "If so, do you know what those risks are?" Question 6: "Have you ever had a stroke?” Finally, question 7 asked about information used to calculate the $\mathrm{CHADS}_{2}$ risk score (Table 1). For better accuracy, we asked what the medications in use were.

We classified the patients as "with basic knowledge" and "without basic knowledge" according to what the authors
Table 1. CHADS score for thromboembolic risk stratification.

\begin{tabular}{lcc}
\hline ABBREVIATION & RISK FACTOR & POINTS \\
\hline $\mathrm{C}$ & Congestive heart failure & 1 \\
$\mathrm{H}$ & Hypertension & 1 \\
$\mathrm{~A}$ & Age $\geq 75$ & 1 \\
$\mathrm{D}$ & Diabetes mellitus & 1 \\
$\mathrm{~S}_{2}$ & Prior stroke or transient ischemic attack & 2 \\
\hline $\mathrm{CHADS}_{2} \geq 2$ indicates treatment with anticoagulation. &
\end{tabular}

expected patients would answer as complications of nonadherence to antithrombotic therapy (question 5). Therefore, answers such as "stroke", "thrombus formation", "hypercoagulability", "embolic situations" or other vascular complications were considered as correct in connection with risks (group A). The only vascular exception was myocardial infarction or heart attack. Different answers not involving a vascular system were considered "without basic knowledge" about antithrombotic therapy (group B).

\section{Data analysis}

Data were analyzed with Software R ( $R$ Core Team, 2015; version 3.2.3). Data description was made through absolute and relative frequencies, means and standard deviations. Fisher's Exact Test was used to correlate variables from questions 4 and 5 and the Difference Between Two Proportions Test, which indicates the probability of a correct decision based on the alternate hypothesis, was applied on data from question 3. The significance level considered was $\mathrm{p}<0.05$.

\section{Ethical aspects}

The study was approved by the Human Research Ethics Committee (protocol 1.207.053), in agreement with Brazilian National Commission for Ethics in Research.

\section{RESULTS}

A total of 150 patients from Brazil's Public Health System were initially interviewed. Seven patients answered "NO" to question 2 and did not follow through on the questionnaire. They were excluded from the statistical analysis and results.

The mean age was $67 \pm 10.65$ years old (about one third of patients were $<65$ years; one third $\geq 65$ and $\leq 74$ years; and one third $\geq 75$ years). Gender distribution was approximately 1:1. In total, 131 (91.6\%) were on anticoagulation therapy with warfarin, and the rest were using antiplatelet agents (Table 2). No-one was using a non-vitamin K antagonist oral anticoagulant.

Ninety-one (63.6\%) patients felt they were informed about the risks of lack of adherence to the treatment (question 4), but when asked to identify what those risks were, only 37 (25.9\%) identified "stroke". Fifty-four (37.7\%) patients said they didn't know of any risk; 20 (14.0\%) identified "blood thickening”; 16 (11.2\%) identified other vascular complications 
such as "thrombosis" and "pulmonary thromboembolism"; 14 $(9.8 \%)$ identified "thrombus formation", "hypercoagulability" or "embolic situations" and 2 (1.4\%) identified "death". No one identified hemorrhagic stroke (Figure).

According to question 5, 67 (46.9\%) patients were included in group A (with basic knowledge) and 76 (53.1\%) patients were included in group B (without basic knowledge).

Among the 91 patients who had been informed about the risks, 63 (69.2\%) showed a basic knowledge (group A) and 28 (30.8\%) did not (group B). Thirty-five (38.4\%) identified "stroke" as a risk factor; $15(16,5 \%)$ identified other vascular complications; 13 (14.3\%) identified "thrombus formation", "hypercoagulability" or "embolic situations"; 16 (17.6\%) identified "blood thickening"; 11 (12.1\%) said they did not know, and $1(1.1 \%)$ identified "death" as a risk factor.
On the other hand, among the 52 patients who said they had never been informed about the risks, 4 (7.7\%) showed a basic knowledge and 48 (92.3\%) did not. Two (3.9\%) of them identified stroke as a risk; 1 (1.9\%) identified other vascular complications; 1 (1.9\%) identified "thrombus formation", "hypercoagulability" or "embolic situations"; 4 (7.7\%) identified "blood thickening"; 43 (82.7\%) said they did not know and $1(1.9 \%)$ identified "death". The correlation between the variables "had been informed" and "not had been informed" was statistically significant ( $\mathrm{p}<0.0001)$.

Forty-two $(29.4 \%)$ patients had a previous history of stroke, $27(64.3 \%)$ of whom were women. Among these 42 patients who had already had a stroke, 16 (38.0\%) identified stroke as a complication from $\mathrm{AF}$ in the case of treatment nonadherence and 26 (62.0\%) did not.

Table 2. Sample characteristics (\%).

\begin{tabular}{|c|c|c|c|c|c|c|}
\hline \multirow{2}{*}{ Variable } & \multicolumn{2}{|c|}{ Total } & \multicolumn{2}{|c|}{ With basic knowledge } & \multicolumn{2}{|c|}{ Without basic knowledge } \\
\hline & $\mathrm{n}$ & $\%$ & $\mathrm{n}$ & $\%$ & $\mathrm{n}$ & $\%$ \\
\hline Female & 75 & 52.4 & 37 & 49.3 & 38 & 50.7 \\
\hline Male & 68 & 47.6 & 30 & 44.1 & 38 & 55.9 \\
\hline Age $<65$ years & 52 & 36.4 & 31 & 59.6 & 21 & 40.4 \\
\hline $65 \geq$ age $\leq 74$ years & 45 & 31.4 & 20 & 44.4 & 25 & 55.6 \\
\hline Age $\geq 75$ years & 46 & 32.2 & 16 & 34.8 & 30 & 65.2 \\
\hline Anticoagulation & 131 & 91.6 & 64 & 48.9 & 67 & 51.1 \\
\hline No anticoagulation & 12 & 8.4 & 3 & 25.0 & 9 & 75.0 \\
\hline $\mathrm{CHADS}_{2}<2$ & 23 & 16.0 & 11 & 47.8 & 12 & 52.2 \\
\hline $\mathrm{CHADS}_{2} \geq 2$ & 120 & 84.0 & 56 & 46.7 & 64 & 53.3 \\
\hline Previous stroke & 42 & 29.4 & 25 & 59.5 & 17 & 40.5 \\
\hline No previous stroke & 101 & 70.6 & 42 & 41.6 & 59 & 58.4 \\
\hline Previous orientation & 91 & 63.6 & 63 & 69.2 & 28 & 30.8 \\
\hline No orientation & 52 & 36.4 & 4 & 7.7 & 48 & 92.3 \\
\hline
\end{tabular}

n: number of patients; \%: percentage of patients; CHADS $_{2}$ : congestive heart failure, hypertension, age $\geq 75$ years, diabetes mellitus, stroke.

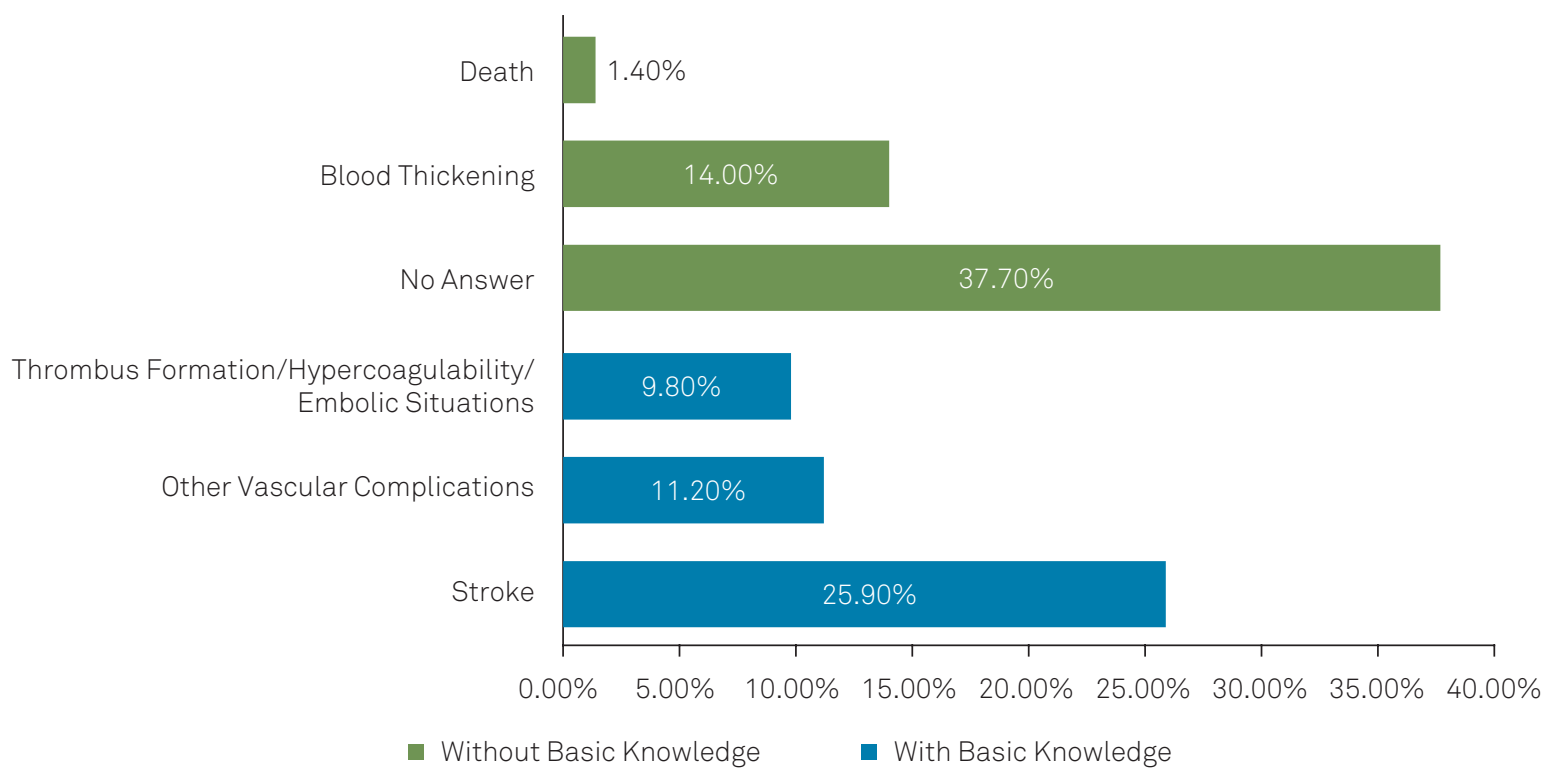

Figure. Patients' knowledge 
Of all the patients with $\mathrm{CHADS}_{2} \geq 2,109(90.8 \%)$ were on anticoagulation and 11 (9.2\%) were taking antiplatelet agents. Of 23 patients with $\mathrm{CHADS}_{2}<2,22$ (95.7\%) were on anticoagulation and 1 (4.3\%) was taking an antiplatelet agent.

\section{DISCUSSION}

According to Hobbs et al. ${ }^{2}$, the worldwide incidence of AF is $1 \%$ to $2 \%$ of the total population. Although the incidence is higher among men, the morbidity and mortality associated with the illness is higher in women ${ }^{12,19,20}$. There were no statistical differences in sex in our sample. The patients' ages were also equivalent to the mean average in other studies.

Our patients showed a good correlation of the $\mathrm{CHADS}_{2}$ score with treatment. Of the patients who were on anticoagulation, only $25.9 \%$ identified stroke as a risk of nonadherence to AF anticoagulant treatment. This alarming number shows us why patients with AF continue to frequently be seen in stroke units, even in the face of a well-known primary risk $^{21,22}$. The crucial role of anticoagulation and adherence to therapy in AF should be as evident for patients as it is to physicians. The level of information should be as clear as possible. Considering the risks of anticoagulation therapy, mainly of warfarin, both types of stroke must be addressed.

An interesting point was that no patient mentioned hemorrhagic stroke or any other hemorrhagic complication of anticoagulation. Although there was no specific question about this, it was expected that patients with full understanding about antithrombotic therapy would mention those risks at some point. However, this result may be a bias from interpretation of the questionnaire.

To improve communication with patients, we should try to understand their reality. Warfarin is the only oral anticoagulant available in Brazil's Public Health System ${ }^{23}$. It is well known that warfarin has many food and drug interactions and demands a strict and frequent control of the international normalized ratio (INR) to avoid risks that are obstacles for optimal treatment ${ }^{24,25}$. Therefore, the patients' education about the disease and its risks is essential to improve adherence and reduce complications ${ }^{26,27,28}$.
The alarming lack of knowledge about basic concepts of $\mathrm{AF}$ and stroke shown in this study might also help explain the high rate of stroke incidence and recurrence. We found that $62.0 \%$ of patients with a previous history of stroke had no knowledge about stroke as a complication of AF. We cannot assume that this lack of knowledge is totally explained by the negligence of medical assistants. Among the 67 patients categorized in group A (with basic knowledge), 63 said they had received previous information about the risks. However, more than two-thirds of the sample did not mention stroke risk in any way, so we can assume that there was a problem in the communication. Inadequate language and lack of effort in teaching the patients may be interrelated. A low socioeconomic and educational level may also have contributed to the patients' poor comprehension, which may be a limitation to the generalization of results. We did not evaluate this.

Anticoagulation therapy had been prescribed for the majority of patients with $\mathrm{CHADS}_{2} \geq 2$, but not for 11 of them. On the other hand, 22 of 23 patients with $\mathrm{CHADS}_{2}<2$ were on warfarin and only one patient was on antiplatelet therapy. We assume that some patients had been recently hospitalized and could be under acute treatment for AF, or that anticoagulation therapy was indicated or contraindicated because of concomitant treatment of other pathologies that were not evaluated by this study ${ }^{29,30}$. The $\mathrm{CHADS}_{2}$ is not the only determinant of anticoagulation. Overall, we found it to be a good therapeutic indication.

The non-vitamin $\mathrm{K}$ antagonist oral anticoagulants are an alternative to stroke prevention in patients with AF. The wider use of these may improve adherence by providing a better quality of life and fewer drug and food interactions, but the risks of stroke and the need for education will still remain a concern ${ }^{9,31}$. In addition, since INR monitoring is not required, the patients' contact with health care professionals may be less frequent, as well as the opportunities to receive effective education.

Better approaches to achieving patient understanding should be considered. Educational campaigns, teaching manuals and adequacy of language could be useful. The physician's compliance with the use of anticoagulants can never be forgotten, irrespective of which drug is administered. We reinforce this with our results.

\section{References}

1. Longo DL, Fauci AS, Kasper DL, Hauser SL, Jameson JL, Loscalzo J Medicina interna de Harrison. 18a ed. Porto Alegre: AMGH, 2013.

2. Hobbs FR, Taylor CJ, Jan Geersing G, Rutten FH, Brouwer JR. European Primary Care Cardiovascular Society (EPCCS) consensus guidance on stroke prevention in atrial fibrillation (SPAF) in primary care. Eur J Prev Cardiol. 2016 Mar;23(5):460-73. https://doi.org/10.1177/2047487315571890

3. Kalantarian S, Ay H, Gollub RL, Lee H, Retzepi K, Mansour M et al. Association between atrial fibrillation and silent cerebral infarctions: a systematic review and meta-analysis. Ann Intern Med. 2014 Nov;161(9):650-8. https://doi.org/10.7326/M14-0538
4. Instituto Brasileiro de Geografia e Estatístca - IBGE. Diretoria de Pesquisas. Coordenação de População e Indicadores Sociais. Projeção da população do Brasil por sexo e idade para o período 2000-2060. Rio de Janeiro: Instituto Brasileiro de Geografia e Estatístca; 2013.

5. Ministério da Saúde (BR). Secretaria de Atenção à Saúde. Departamento de Atenção Especializada. Manual de rotinas para atenção ao AVC. Brasília, DF: Ministério da Saúde; 2013

6. Santos C, Pereira T, Conde J. CHADS2 score in predicting cerebrovascular events: a meta-analysis. Arq Bras Cardiol. 2013 Mar;100(3):294-301. https://doi.org/10.5935/abc.20130068 
7. Ministério da Saúde (BR). Secretaria de Atenção à Saúde. Departamento de Ações Programáticas Estratégicas. Diretrizes de atenção à reabilitação da pessoa com acidente vascular cerebral. Brasillia, DF: Ministério da Saúde; 2013.

8. Adam SS, McDuffie JR, Ortel TL, Williams JW Jr. Comparative effectiveness of warfarin and new oral anticoagulants for the management of atrial fibrillation and venous thromboembolism: a systematic review. Ann Intern Med. 2012 Dec;157(11):796-807. https://doi.org/10.7326/0003-4819-157-10-201211200-00532

9. Verheugt FW, Granger CB. Oral anticoagulants for stroke prevention in atrial fibrillation: current status, special situations, and unmet needs. Lancet. 2015 Jul;386(9990):303-10. https://doi.org/10.1016/S0140-6736(15)60245-8

10. de Lima Silva RG, Bertollo CM, Ferreira IG, Brant LC, Martins MA. Assessment of oral anticoagulation control at two pharmacistmanaged clinics in Brazil. Int J Clin Pharm. 2017 Dec;39(6):1157-61. https://doi.org/10.1007/s11096-017-0511-x

11. Martins MA, Costa JM, Mambrini JV, Ribeiro AL, Benjamin EJ, Brant LC et al. Health literacy and warfarin therapy at two anticoagulation clinics in Brazil. Heart. 2017 Jul;103(14):1089-95. https://doi.org/10.1136/heartjnl-2016-310699

12. Mason PK, Lake DE, DiMarco JP, Ferguson JD, Mangrum JM, Bilchick K et al. Impact of the CHA2DS2-VASc score on anticoagulation recommendations for atrial fibrillation. Am J Med. 2012 Jun;125(6):603.e1-6. https://doi.org/10.1016/j.amjmed.2011.09.030

13. Lip GY, Nieuwlaat R, Pisters R, Lane DA, Crijns HJ. Refining clinical risk stratification for predicting stroke and thromboembolism in atrial fibrillation using a novel risk factor-based approach: the euro heart survey on atrial fibrillation. Chest. 2010 Feb;137(2):263-72. https://doi.org/10.1378/chest.09-1584

14. Klein D, Levine M. Are family physicians using the CHADS2 score? Can Fam Physician. 2011;57(8):e305-9.

15. Karthikeyan G, Eikelboom JW. The CHADS2 score for stroke risk stratification in atrial fibrillation: friend or foe? Thromb Haemost. 2010 Jul;104(1):45-8. https://doi.org/10.1160/TH09-11-0757 •

16. Nóvak EM, Zétola VH, Muzzio JA, Puppi M, Carraro Júnior H, Werneck LC. [Lay knowledge about stroke]. Arq Neuropsiquiatr. 2003 Sep;61(3B):772-6. Portuguese. https://doi.org/10.1590/S0004-282X2003000500013

17. Pontes-Neto OM, Silva GS, Feitosa MR, Figueiredo NL, Fiorot Junior JA, Rocha TN et al. Stroke awareness in Brazil: alarming results in a community-based study. Stroke. 2008 Feb;39(2):292-6. https://doi.org/10.1161/STROKEAHA.107.493908

18. Campos-Sousa RN, Soares VY, Almeida KJ, Carvalho LI, Jacobina KS, Athayde Netto AE et al. Knowledge of stroke among a Brazilian urban population. Arq Neuropsiquiatr. 2007 Sep;65(3a 3A):587-91. https://doi.org/10.1590/S0004-282X2007000400007

19. Andrade JG, Deyell MW, Lee AY, Macle L. Sex differences in atrial fibrillation. Can J Cardiol. 2018 Apr;34(4):429-36. https://doi.org/10.1016/j.cjca.2017.11.022
20. Schnabel RB, Yin X, Gona P, Larson MG, Beiser AS, McManus DD et al. 50 year trends in atrial fibrillation prevalence, incidence, risk factors, and mortality in the Framingham Heart Study: a cohort study. Lancet. 2015 Jul;386(9989):154-62. https://doi.org/10.1016/S0140-6736(14)61774-8

21. Cabral NL, Volpato D, Ogata TR, Ramirez T, Moro C, Gouveia S. [Atrial fibrillation, stroke and anticoagulation: under-use of warfarin?] Arq Neuropsiquiatr. 2004 Dec;62(4):1016-21. Portuguese. https://doi.org/10.1590/S0004-282X2004000600016

22. Amaral CH, Amaral AR, Nagel V, Venancio V, Garcia AC, Magalhaes PS et al. Incidence and functional outcome of atrial fibrillation and nonatrial fibrillation- related cardioembolic stroke in Joinville, Brazil: a population-based study. Arq Neuropsiquiatr. 2017 May;75(5):288-94. https://doi.org/10.1590/0004-282×20170039

23. Ministério da Saúde (BR). Secretaria de Ciência, Tecnologia e Insumos Estratégicos. Departamento de Assistência Farmacêutica e Insumos Estratégicos. National relation of essential medicines: RENAME. Brasília, DF: Ministério da Saúde; 2017.

24. Morgan CL, McEwan P, Tukiendorf A, Robinson PA, Clemens A, Plumb JM. Warfarin treatment in patients with atrial fibrillation: observing outcomes associated with varying levels of INR control. Thromb Res. 2009 May;124(1):37-41. https://doi.org/10.1016/j.thromres.2008.09.016

25. Xie Z, Tian Y, Lv X, Xiao X, Zhan M, Cheng K et al. The selectivity and bioavailability improvement of novel oral anticoagulants: an overview. Eur J Med Chem. 2018 Feb;146:299-317. https://doi.org/10.1016/j.ejmech.2018.01.067

26. Silva T, Schenkel EP, Mengue SS. [Patient knowledge about drugs prescribed in a teaching hospital]. Cad Saude Publica. 2000;16(2):44955. Portuguese. https://doi.org/10.1590/S0102-311X2000000200015

27. Hernández Madrid A, Potpara TS, Dagres N, Chen J, Larsen TB, Estner $\mathrm{H}$ et al. Differences in attitude, education, and knowledge about oral anticoagulation therapy among patients with atrial fibrillation in Europe: result of a self-assessment patient survey conducted by the European Heart Rhythm Association. Europace. 2016 Mar;18(3):463-7. https://doi.org/10.1093/europace/euv448

28. Potpara TS, Pison L, Larsen TB, Estner H, Madrid A, BlomströmLundqvist $\mathrm{C}$ et al. How are patients with atrial fibrillation approached and informed about their risk profile and available therapies in Europe? Results of the European Heart Rhythm Association Survey. Europace. 2015 Mar;17(3):468-72. https://doi.org/10.1093/europace/euv025

29. Zimerman LI, Fenelon G, Martinelli Filho M, Grupi C, Atié J, Lorga Filho A et al. Sociedade Brasileira de Cardiologia. Diretrizes Brasileiras de Fibrilação Atrial. Arq Bras Cardiol. 2009;92(6 supl. 1):1-39.

30. Camm AJ, Kirchhof P, Lip GY, Schotten U, Savelieva I, Ernst S et al. Guidelines for the management of atrial fibrillation: the task force for the management of atrial fibrillation of the European Society of Cardiology (ESC). Eur Heart J. 2010 Oct;31(19):2369-429. https://doi.org/10.1093/eurheartj/ehq278

31. Connolly SJ, Ezekowitz MD, Yusuf S, Eikelboom J, Oldgren J, Parekh A. Dabigatran versus warfarin in patients with atrial fibrillation. N Engl J Med. 2009 Sep;361(12):1139-51. https://doi.org/10.1056/NEJMoa0905561 